\title{
Collaboration in EFL Classes: Listening to Teachers' and Students' Voices
}

\author{
L.P. Artini ${ }^{1}$, N.M. Ratminingsih ${ }^{2}$, N.N. Padmadewi ${ }^{3}$ \\ Universitas Pendidikan Ganesha \\ Bali, Indonesia \\ 1putu.artini@undiksha.ac.id, ${ }^{3}$ nym.padmadewi@undiksha.ac.id
}

\begin{abstract}
The $21^{\text {st }}$ century learning is characterized by the 4Cs: Collaboration, Creativity, Critical Thinking, and Communication. Pedagogical practices, therefore, should accommodate interactions and active thinking among students. Putting students into groups is one strategy that can be expected to encourage collaborative learning, communication, as well as high order thinking skills. This study aims at describing how groupings are planned and implemented by EFL teachers in junior high schools in Bali. The study followed a descriptive qualitative research paradigm involving 8 English teachers from 4 public schools and 154 students of Grade 8. The data were collected through classroom observation, document study, questionnaire, and interview. The study found that among the range of grouping formats, EFL teachers showed monotonous grouping strategies that involve students to work on a task. Most of the strategies are spontaneously assigned to students as the lesson flows. Only $41.9 \%$ of group activities are planned, which mostly involve students to work in pairs or in a small group (buzz group). The majority of students $(81.3 \%)$ perceived that working in groups give them a chance to learn better. However, the limited types of grouping employed in the classroom tend to create monotonous classroom atmosphere. The data from interview revealed that teachers perceived that not many types of cooperative learning can be practiced because of the limited time available for teaching 'a big topic'. It is also perceived that learning occurs in any group activities, and interaction can be expected to occur regardless of grouping types used.
\end{abstract}

Keywords-collaborative learning; ELF classes

\section{INTRODUCTION}

\section{A. Teaching English as a Foreign Language in the 21 Century}

In a non-English speaking country, English is considered as an asset for better employment [3], so this usually affects young people's motivation to learn the language [14]. As language is not used in the community, an English teacher has a major role for the learning success [17]. S/he should not only have various teaching strategies but also be updated with the latest trends in teaching, as well as able to create learning contexts that make students learn the use of the language for communication. The major trend that influences classroom activities nowadays is the $21^{\text {st }}$ learning which emphasizes collaboration, critical thinking, creativity, and communication. Thus, an English teacher should be able to create activities that provide students with opportunities to learn through collaborative / cooperative work [6], think critically, be creative, and communicate with one another using the target language [8].

A teacher has an authority to decide on the types of collaborative task, and assign them to work in groups. Grouping strategies can be considered as one determining variables for success in foreign language learning. By working with others, students do not only have the opportunity to practice the language but also to collaborate to build motivation, enthusiasm, and confidence in speaking the target language [25]. Working in groups trains students to take responsibility to own learning, which will result in self-directedness in learning [4]. It also supports the $21^{\text {st }}$ century learners to build the abilities for collaboration, critical thinking, creativity, and communication [20]. The appropriate grouping format and tasks will gradually improve collaborative and critical thinking skills, as well as an ability to communicate and become creative. When working in groups, students communicate and support one another, and make a plan, decision or consensus together.

Since the education reform, which is marked by the launching of Curriculum 2013, Indonesian schools are required to take the $21^{\text {st }}$ learning characteristics into account. School programs should yield students' ability to collaborate, think critically, as well as to become creative and communicative [20]. The class activities need to be designed in such a way that students have ample opportunities to interact, discuss, teamwork, and speak in order to achieve the requirement. As a matter of fact, making decision about which teaching strategies to use becomes the most challenging part of teaching a foreign language, especially when the class is big (Cheng \& Dornyei, 2008).

Student-centered learning activities should become a priority in a lesson, especially in the form of interesting, relevant, and engaging tasks for the students to work on (Jonassen, 2000). Every teacher can be expected to have their own ideas about conducting a collaborative class. It is then interesting to explore how the English teachers in junior high schools in north Bali planned, executed, and assessed collaborative activities in English as a Foreign Language (EFL) classes. Teachers are different in term of experiences in teaching [7], that may affect their ability to make decision [23]. This study is an attempt to describe what grouping strategies used by EFL teach- 
ers during the teaching and learning process, and what the teachers and students think about grouping strategies used in the classroom.

\section{B. Collaborative Learning in EFL classes}

Collaborative learning is widely accepted as an educational approach to teaching and learning that involves the activity of putting students to work in groups to solve problems, to work on a project, or to complete a task [10]. The importance of collaborative learning is underlined by the theory that learning is 'a social act' that learners should work in a group and talk (Gerlach, 1994). In the $21^{\text {st }}$ century learning, working in groups will help students to build collaborative skills, which are very important to be possessed by every member of the society.

There are various collaborative grouping strategies that can be found in the literature, many of which are cooperative in nature. Cooperative groupings have specific characteristics in which every individual in the group will learn from one another and they are responsible to achieve the same learning goal together $[21,22,13,18]$. Collaborative grouping strategies may be formed based on number of students (pair, small group, big group, class team, whole class), or based on how students work when they are put into groups. The latter groupings include, for example, Think-Pair-Share(Lyman, 1987, as cited in Azlina, 2010); Buzz Group [2]; Rotating Trios Exchange [21]; Jigsaw [22,24]; Student Teams-Achievement Divisions [22,13,24,12,15]; and Team Games Tournament [6,22,13]. These groupings require students to think individually, discuss in pairs or small groups, make peer tutor, make consensus, answer questions, compete, do quizzes, and so forth. These activities will make them cooperate and collaborate, and every student has his/her own responsibility to contribute positively either to his/her group achievement or to own learning development.

\section{Perception}

Perception is considered as conscious sensory experiences about something. This 'something' is transformed by the brain into an internalized knowledge, feeling and impressions about something [9]. Perceptions may also be defined as a process of acquiring and processing information [5]. This scholar suggests two theories in relation to processing sensory data: first, the bottom-up theories, in which the processing starts from the lowest sensory level to the highest. This is responsible for more 'global and abstract' ways of thinking. Second, the topdown theories, which started from the background knowledge or prior experience downward and responsible for more "feeling" related to sensory stimulus. In the context of the present study, perceptions are related to the top-down theories, in which the subject of the study (i.e. teachers and students) have the experience of using or experiencing the grouping strategies and are requested to speak about how they feel about it.

\section{METHOD}

\section{A. Subject and Object of the Study}

The subjects of this study were 8 English teachers and 154 Grade 8 students from 4junior high schools in north Bali, Indonesia. The schools and subjects were determined through simple cluster sampling technique.

\section{B. Object of the Study}

The objects of the study were grouping strategies which were implemented in English classes in Junior High Schools in North Bali, Indonesia; and the teachers' and students' perceptions about grouping strategies used in the classrooms.

\section{Research instruments}

Methodological triangulation was used in this research to assure the validity of the data (Flick, et al., 2004). For this, three instruments used to obtain the data: (1) document study (to describe the use of grouping strategies in the classroom); (2) classroom observation sheet (to identify the use of grouping strategies in the teachers' lesson plans); (3) interview guides to students and teachers (to 'listen to the voices' of the students and teachers about the use of grouping strategies in English classes.

\section{E. Data Analysis}

The data analysis follows [16]. 3 sets of data are triangulated to minimize the potential bias in interpreting the findings.

\section{RESULTS AND DISCUSSION}

\section{A. Grouping strategies in the lesson plans}

The first major finding is that learning mostly occurs by route since grouping strategy does not involve adequate collaboration that trained students to be communicative and working as a team (Gerlach, 1994\& Harmer, 2007). From 12 lesson plans collected, $8(66.7 \%)$ of them included one or more grouping strategies, as seen from the table below.

TABLE I. GROUPING STRATEGY IN THE LESSON PlanS

\begin{tabular}{|l|l|l|l|l|}
\hline \multirow{2}{*}{ LP No } & \multicolumn{4}{|c|}{ Number of GS in Lesson Segments } \\
\cline { 2 - 5 } & Pre Activity & $\begin{array}{c}\text { Whilst Ac- } \\
\text { tivity }\end{array}$ & $\begin{array}{c}\text { Post Activi- } \\
\text { ty }\end{array}$ & Total \\
\hline LP\#1 & - & 1 & - & 1 \\
\hline LP\#2 & - & - & - & 0 \\
\hline LP\#3 & - & 2 & - & 2 \\
\hline LP\#4 & - & 1 & - & 1 \\
\hline LP\#5 & - & 2 & 1 & 3 \\
\hline LP\#6 & - & - & - & 0 \\
\hline LP\#7 & - & 2 & - & 2 \\
\hline LP\#8 & - & 2 & 1 & 3 \\
\hline LP\#9 & - & 3 & - & 3 \\
\hline LP\#10 & 1 & 2 & - & 3 \\
\hline LP\#11 & - & - & - & 0 \\
\hline
\end{tabular}




\begin{tabular}{|l|l|l|l|l|}
\hline \multirow{2}{*}{ LP No } & \multicolumn{4}{|c|}{ Number of GS in Lesson Segments } \\
\cline { 2 - 5 } & Pre Activity & $\begin{array}{c}\text { Whilst Ac- } \\
\text { tivity }\end{array}$ & $\begin{array}{c}\text { Post Activi- } \\
\text { ty }\end{array}$ & Total \\
\hline LP\#12 & - & - & - & 0 \\
\hline
\end{tabular}

Note: LP (Lesson Plan)

GS (Group Strategy)

In the first lesson plan, for example, the topic was about descriptive text. The grouping strategy was stated in the main activities: "Students work in groups of $4 \mathrm{~s}$ and discuss about the generic structure of a descriptive text". Grouping strategy occurs only in the main activities which took approximately $80 \%$ of allocated time for a lesson. During the 10 weeks of data collection process in the schools, the topics were: descriptive texts (describing a person, object, and animal); recount text (personal, factual); and short functional texts (invitation and announcement). In addition to those, some language features were included, such as the use of tenses, the use of countable nouns, and expressions of agreement and disagreement. These mostly require teachers to explain so that the impact of the $21^{\text {st }}$ learning as put forward by Rotherham\& Willingham (2009) may hardly be achieved [20].

\section{B. Grouping Strategies in the classrooms}

The second data set was from the classroom observation. In this data collection, the actual implementation of the grouping strategies was observed and compared to those planned in the lesson plans. In the 16 lessons observed, the implementation of grouping strategies is varies as seen in the following table.

TABLE II. GROUPING STRATEGIES EMPLOYED IN EFL CLASSES

\begin{tabular}{|c|c|c|c|c|}
\hline \multirow[t]{2}{*}{ LP No } & \multicolumn{4}{|c|}{ GS observed in Lesson Segments } \\
\hline & $P A$ & $W A$ & $P A$ & Total \\
\hline LP\#1L1 & - & 1 & - & 1 \\
\hline LP\#1L2 & 1 & 2 & - & 3 \\
\hline LP\#2L1 & - & 2 & - & 2 \\
\hline LP\#2L2 & 1 & 3 & - & 4 \\
\hline LP\#3L1 & - & 2 & - & 2 \\
\hline LP\#3L2 & 1 & 2 & - & 3 \\
\hline LP\#4L1 & - & 2 & - & 2 \\
\hline LP\#4L2 & 1 & 2 & 1 & 4 \\
\hline LP\#5 & - & 2 & 1 & 3 \\
\hline LP\#6 & 1 & 1 & 1 & 3 \\
\hline LP\#7 & - & 2 & 1 & 3 \\
\hline LP\#8 & - & 2 & 1 & 3 \\
\hline LP\#9 & - & 3 & - & 3 \\
\hline LP\#10 & 1 & 2 & 1 & 4 \\
\hline LP\#11 & - & 1 & - & 1 \\
\hline LP\#12 & - & 2 & - & 2 \\
\hline & & & $\begin{array}{r}\mathrm{N} \\
\mathrm{L} 1, \mathrm{~L} 2\end{array}$ & $\begin{array}{l}\text { P (Lesson Plan) } \\
\text { Group Strategy) } \\
\text { on 1, Lesson 2) } \\
\text { A (Pre Activity) } \\
\text { Whilst Activity) } \\
\text { (Post Activity) }\end{array}$ \\
\hline
\end{tabular}

In general, the use of grouping strategies in the lesson plans and in classroom activities is not always consistent. The teaching and learning process sometimes did not follow the lesson plan or what planned was not closely followed in the real implementation. An effective classroom should be preceded by a clear planning [19].

In some lessons, the frequency in using grouping strategy in the lesson plan was not the same as it in the teaching and learning process in the classroom. For example, in Lesson Plan 2, there is no grouping strategy was planned, however, in the actual teaching and learning, students were assigned to work in groups five times (twice in the first lesson and three times in group activities the second lesson). Only $41.9 \%$ group activities were planned which indicates that many grouping strategies were spontaneously assigned to students

The findings showed that there were many unplanned group activities in the classroom. It indicated that collaborative activities are not prioritized so that the 21 st century learning may not effectively be addressed in the classroom. This is not in line with the expectation of the new curriculum that requires teachers to be creative in developing collaborative activities in the classroom (Info Guru Indonesia, 2017). In most cases, teachers did not have special rules for group formations. Students are assigned to immediately form their groups with peers seating next to them. This is not in conformity with the criteria of cooperative grouping, for instance, the students must be heterogeneous and positively independent from one another [22].

\section{Teachers' and students' perceptions about grouping in the classroom.}

There are three indicators in relation to students' perceptions: the impact of grouping strategy used on students' learning; the importance of grouping strategies on students' learning; and the media used by the teachers when putting students into groups.

TABLE III. STUDENTS' PERCEPTIONS ABOUT GROUPING STRATEGY USED IN CLASS ACTIVITIES

\begin{tabular}{|l|l|l|l|l|}
\hline & \multicolumn{1}{|c|}{ Indicators } & $\begin{array}{c}\text { Positive } \\
(\boldsymbol{\%})\end{array}$ & $\begin{array}{c}\text { Negative } \\
(\boldsymbol{\%})\end{array}$ & \multicolumn{1}{|c|}{ Note } \\
\hline Students' & $\begin{array}{l}\text { Impact of GS on } \\
\text { learning }\end{array}$ & 80.0 & 1.1 & $\begin{array}{l}17.9 \% \text { unde- } \\
\text { cided }\end{array}$ \\
$\begin{array}{l}\text { Percep- } \\
\text { tions about }\end{array}$ & $\begin{array}{l}\text { Importance of } \\
\text { GS }\end{array}$ & 81.3 & 18.7 & $\begin{array}{l}\text { No undecid- } \\
\text { ed idea. }\end{array}$ \\
\cline { 2 - 5 } & $\begin{array}{l}\text { Media used for } \\
\text { GS }\end{array}$ & 41.4 & 28.3 & $\begin{array}{l}30.3 \% \text { unde- } \\
\text { cided }\end{array}$ \\
\cline { 2 - 5 } & Average & 67.6 & 16 & - \\
\cline { 2 - 5 } & \multicolumn{3}{|c|}{ Note: GS = Grouping Strategy }
\end{tabular}

The table reveals that in general students have positive perceptions about the implementation of grouping strategies in EFL classes. In other words, students like strategies that allow them to work with others in a group. The majority of the students $(81.3 \%)$ perceive that working in groups during the teaching and learning process is a positive support to their 
learning. In term of the use of media during the implementation of grouping strategy, $41.4 \%$ of the students show positive perceptions. This means that these students appreciate teachers' facilitation in group work activities. The media such as handouts and unscrambled sentences are found to be used by the teacher when assigning the students to work in groups. However, $30.3 \%$ of the students are undecided when question about media used in group work was asked. This is probably because the use of media was not obvious that not all students notice their use.

Overall, positive perceptions on the part of the students can be treated as an indicator of students' satisfaction about the implementation on grouping strategies in the classroom. Even though the types of grouping used are limited (mostly buzz groups that can be assigned spontaneously and for doing simple tasks), this has been considered appropriate for many students.

Three reasons for limited types of grouping strategies used by the teachers appeared from the interview. First, limited time allocation for 'a big topic' make it not possible to use cooperative learning because it takes a long time. Second, the teacher considered that learning occurs when students are put into groups, regardless of the types. Third, interactions occur similarly no matter what grouping strategies used.

These perceptions about the implementation of groping strategies came from the teacher. It seems that they are lack of experiences in conducting cooperative learning that include the implementation of a wide range of groupings that make learning more collaborative and effective $[20,12,15]$.

\section{CONCLUSION}

Collaborative learning is important and requires teachers to have a big 'collection' of grouping strategies. This study indicates that EFL teachers in Bali, Indonesia might have known various types of collaborative group activities, however, the allocation of time was considered as an obstacle to implement them in a lesson. Cooperative groupings are also not a preference since it is considered complicated and time consuming. This study also found that there were some inconsistencies between what teachers planned and what executed in the classroom. This also is likely to be caused by teachers' inconfidence and limited knowledge and experience to implement various grouping strategies. Therefore, it is suggested that the government should play a role to provide professional development in collaborative learning to EFL teachers in Indonesia.

\section{REFERENCES}

[1] N.N. Azlina, "CETLs: supporting collaborative activities among students and teachers through the use of think-pair-share techniques," International Journal of Computer Science Issues, vol. 7, no. 5, pp. 1829,2010 .

[2] Y. Bejarano, A Cooperative Small- Group Methodology in the Language Classroom. Tesol Quarterly, vol. 21, no. 3, pp. 483-504, 1987.

[3] K. Bolton, "English in Asia, Asian Englishes, and the issue of proficiency," English Today, vol. 24, no. 2, pp. 3-12, 2008.

[4] S,D. Brookfield, Self-Directed Learning'in R Maclean \& D Wilson (eds),International Handbook of Education for the Changing World of Work, Springer, Dordrecht, 2009.

[5] A. Demuth,'Perception theories', Department of Philosophy, Faculty of Philosophy, Trnava. 2013.

[6] D.L. DeVries, Student Teams Can Improve Basic Skills: TGT Applied to Reading.https://eric.ed.gov/?id=ED136130, 1976.

[7] E. Gatbonton, Looking beyond teachers' classroom behaviour: Novice and experienced ESL teachers' pedagogical knowledge. Language Teaching Research, vol. 12, no. 2, pp. 161-182, 2008.

[8] G.V. Glass, "Grouping students for instruction," School reform proposals: The research evidence, pp. 95-112, 2002.

[9] E.B. Goldstein (Ed), Encyclopedia of perception (Vol. 1). Sage, 2010.

[10] J. Harmer, The practice of English language teaching, Pearson Longman, Harlow, 2007.

[11] D.H. Jonassen, Revisiting activity theory as a framework for designing student-centered learning environments. Theoretical foundations of learning environments, pp. 89-121, 2000.

[12] G.N. Khan, and H.M. Inamullah, "Effect of student's team achievement division (STAD) on academic achievement of students" Asian Social Science, vol. 7, no. 12, pp. 211-218, 2011

[13] R. Killen, Effective teaching strategies lessons from research to practice, Social Science Press: Australia, 1996.

[14] M. Lamb, "Integrative motivation in a globalizing world," System, vol. 32, no.1, pp. 3-19, 2004.

[15] M.I. Majoka, M.H. Dad, and T. Mahmood, "Student team achievement division (STAD) as an active learning strategy: Empirical evidence from mathematics classroom," Journal of Education and Sociology, vol. 4, pp. 16-20, 2010.

[16] M.B. Miles, A.M. Huberman, and J. Saldana, Qualitative data analysis: A sourcebook, American educational research association, Beverly Hill, 1984.

[17] Y. Nae-Dong, "Exploring a new role for teachers: promoting learner autonomy," System, vol. 26, no. 1, pp. 127-135, 1998.

[18] R.L. Oxford, "Cooperative learning, collaborative learning, and interaction: three communicative strands in the classroom" The Modern Language Journal, vol. 81, no 4, pp. 443-456, 1997.

[19] B.E. Peterson, BE "Student teaching in Japan: the lesson," Journal of Mathematics Teacher Education, vol. 8, no. 1, pp. 61-74, 2005.

[20] A.J. Rotherham, and D. Willingham, "21st century," Educational leadership, vol.67, no. 1, pp. 16-21, 2009.

[21] M.L. Silberman, 101 ways to make training active (Vol. 1). John Wiley \& Sons, 2011.

[22] R. E. Slavin, Cooperative learning. Review of educational research, vol. 50, no. 2, pp. 315-342, 1980.

[23] M. Tschannen-Moran, and A.W. Hoy, "The differential antecedents of self-efficacy beliefs of novice and experienced teachers," Teaching and teacher Education, vol. 23, no. 6, pp. 944-956, 2007.

[24] L.T.Tuan, Infusing Cooperative learning into an EFL classroom. English Language Teaching, 3(2), 64-77, 2010.

[25] H. Zhou, H "Enhancing non-English majors' EFL motivation through cooperative learning," Procedia environmental sciences, vol. 12, pp. 1317-1323, 2012. 